\section{Financial Crises in Comparative Perspective - Crisis Management and its Phenomenon of Repetition/Return}

\section{Sebastian Zemla}

PhD Student at the University of Applied Sciences Burgenland, Austria and Juraj Dobrila University of Pula, Faculty of Economics and Tourism “Dr. Mijo Mirković", Croatia

1819001103@fh-burgenland.at

\begin{abstract}
Crises cause attentiveness in our society and awaken, depending on the degree of consternation, our ongoing interest. These events include financial crises, phenomenal incidents that shock the economic world and pose significant challenges for the governments. Two crises which stand out in this context are the Great Depression in 1929 and the financial crisis in 2007/2008. In addition to the comparative approach, the paper focuses directly on the typical repetitive mechanism ("recurrent pattern of banking and sovereign debt crises" (Reinhart \& Rogoff, 2011): overheating, the forming of a bubble and the bursting of the bubble, largely started in the USA. Specific aspects included in this research area are crisis management in the decades mentioned above, the role of governments and banks, as well as the observation as to which crisis can be expected next. We can conclude that the current monetary systems led by complex financial instruments and addicted to low interest rates are prone to deliver another serious financial crisis.
\end{abstract}

Keywords: financial crises, comparison of crises, crisis management, government measures, future inevitability

\section{Introduction}

\section{Topical introduction}

Crises trigger attention in society and arouse our further interest, depending on the degree of the concern raised. In the recent past, this was the case with the financial crisis which started in 2007 in the USA and in 2008 in Europe and became the primary topic in domestic as well as foreign news unlike any other before. The causes of the crisis are unambiguous and focus on the dramaturgical structure of the real estate bubble in the USA, whose bursting should prove particularly momentous (Zeise, 2010, p. 9). In the context of the evaluation of its background and time factors, its origins can be traced almost a decade back, to March 2000, when the bubble forming around "new economy" companies burst. Emerging investor interests in this segment became dependent variables in the process of corporate start-ups and
REVIEW PAPER

RECEIVED: OCTOBER 2019

REVISED: JANUARY 2020

ACCEPTED: FEBRUARY 2020

DOI: 10.2478/ngoe-2020-0006

UDK: 330.3:005:338.246

JEL: G15, G18, G21, 016, N2

Citation: Zemla, S. (2020). Financial Crises in Comparative Perspective -

Crisis Management and its

Phenomenon of Repetition/Return. Naše gospodarstvo/Our Economy, 66(1), 65-77. DOI: 10.2478/ngoe-2020-0006

\section{NG OE}

NAŠE GOSPODARSTVO OUR ECONOMY

\begin{tabular}{l|l|l} 
Vol. 66 & No. 12020 \\
\hline
\end{tabular}

pp. $65-77$ 
increased the emergence of initial public offerings. Investors' expectations in technology-oriented companies were often unrealistic and fictitious. Under the escort of commercializing circumstances, they provided a clue to exaggerated valuations of the companies, which came to a substantial end with the bursting of the so-called "dotcom" bubble (Chorafas, 2009, p. 89; Zandi, 2009, p. 5; Bischoff, 2008, p. 61; Jahnke, 2008, p. 5; Glebe, 2008, p. 104).

The terrorist attack in New York on September 11, 2001 is also categorized as a burdening factor, as planes hijacked by terrorists caused the collapse of the World Trade Center towers and contributed to the downturn of the world stock markets (Henkel, 2009, p. 70). Consequently, global financial markets were considerably impacted and the economic circle reacted nervously. In order to prevent a prolonged decline on the American stock exchange, including the consequential effects of weakening the US economy, the Federal Reserve System used the instrument of low interest rate policy as a countermeasure (Jahnke, 2008, p. 5). The effects of the financial crisis were visible not only at the national level, but also had harmful consequences for the global economy, in particular Europe and thus also Germany. The Federal Ministry of Economics and Technology even categorized it as "the worst economic crisis since the Federal Republic of Germany” (BMWi, 2012).

It was therefore only a matter of time before economists, politicians, political scientists and contemporary, were inclined to compare the current crisis and the crisis of the 1930s. "Black Friday" and the resulting stock market crash, the beginning of the US economic crisis as well as the suffering of the national economy led to many perspectives in crisis awareness, and at the same time evoking memories of sad scenarios (Jahnke, 2009, p. 9). The origin of the crisis in the USA is obvious and opens space for some relevant commonalities in both events. The topic of this paper is based on a comparative crisis debate induced over a couple of years. The paper aims to evaluate the essential parallels and distinctions regarding both the great financial and economic crisis, and additionally, to illustrate the phenomenon of repetition that is their characteristic mechanism.

\section{Research question}

The discussion concerning the comparability of both periods, including their causation and impacts, considers both economic and political aspects, and looks for similarities and divergences. Reflecting on the above object of investigation, the research question is as follows:
What are the main parallels and differences between two major crises that are distant in time, and what insights do they allow regarding future repetition?

\section{Methodological approach}

The author uses the methodology of qualitative research and, partially, the service of comparing political science. Something that cannot be neglected in the comparison of the financial and economic crisis, however, is that this is a difficult and very complex topic, of which individual parts have already been addressed by a wide variety of scientific disciplines. Its interdisciplinary approach includes, in addition to economic science as the main field, also political science affected by historical elements. The examination of financial crises offers -because of its complex content - a wide range of experimental opportunities, including a descriptive, analytical, empirical or comparative approach. This is further indicated by the fact that a variety of works and publications are available among others in the subject area of crisis management, trade cycle policy, globalization as well as comparative economic history. In this context, the following versions of Bellers and Kipke are suitable for the research plan. They use the example of a "relatively late arised political science" to describe that "no science ... - quasi self-sufficient - can evolve from itself” (Bellers \& Kipke, 2006, p. 221). As a result of this, a recourse to the located methods there is appropriate. As the research question has a comparative character, comparative examination methods should be applied. It should be noted that comparative methods take effect both in economic and political sciences, only the positioning diverges. Nohlen remarked that, in social science, the comparative studies can be the method that is most relatable to political science (Nohlen, 1994, p. 507). A good example is a comparison regarding different government policies, which is suitable in many ways, where policy results ("outcome") can be compared. In this regard, it is possible -on the basis of comparative illustration and declaration - to learn from experiences, successes and failures of previous periods and time sections (Schmidt, 1988, p. 2).

Along with the systematical comparisons, Berg-Schlosser and Müller-Rommel noticed that, in the discipline of comparative political science, complementary applications could also come into effect, for example historical comparative methods (Berg-Schlosser, 2013, p. 14). For example, the "comparative science of history" - according to the explanations of the historian Marc Bloch - looks "for similarities and differences in analogue rows from different social areas in order to explain them.” In fact, the compared objects - in the present investigation, the two crises - will be analysed separately to compare them subsequently in certain aspects (Bloch, 2000, p. 115-116). 


\section{Comparisons}

\section{Crisis of the 1930s}

\section{Before the outbreak}

The origin of the 1930s crisis goes back to the First World War and its events. The war and its consequences led the industrial countries in Europe, such as France, England and especially Germany, to forfeit large parts of their positions (Rothermund, 1993, p. 22-23), causing the death of over 10 million people and twice as many injuries (Rattner \& Danzer, 2007, p. 20). In addition, there were countless losses of labour as well as an enormous increase in debt (Ullmann, 2003, p. 226). The USA entered the war in 1917 and profited from the economic destruction in Europe. This includes the economics of war which helped large American companies to increase their production capacities andlay the basis for double added value from 1914 to 1919. Further developments appeared in form of a change in the leading currency from British Pound to US Dollar, and simultaneously, the shift from the major financial centre in London to New York (Jaeger, 1973, p. 49-55; Menzel, 2010, p. 98). The postwar period in the USA was characterized, due to these developments, by a conspicious balance of payments surplus, in particular relative to higher exports of goods and capital towards Europe (Rothermund, 1993, p. 48). According to Galbraith, the nineteen-twenties and the subsequent years were, not accidentally but as expected, economically successful for the USA. Production figures from 1925 to 1929 showed an increase of over 10\%, and the automotive industry registered a rise of $25 \%$ in incoming orders (Galbraith, 2009, p. 34-35).

The defeat in the First World War led to Germany's predicament to settle reparation payments (Plumpe, 1984, p. 56). To build up liquidity in subsequent years, Germany was dependent on American credits that were responsible for the reconstruction and an upswing in the German economy. Blaich described this period with terms like "dollar bill blossom" or "living off credit", even though investment activities in the mid-nineteen-twenties were increasing, for example in transport infrastructure, administration buildings, schools, flats and hospitals (Blaich, 1990, p. 79). This economic recovery entered history as the "roaring twenties" in which the USA and many European countries were in upswing, mainly driven by credit financed speculation fever (Plumpe, 2011, p. 80-81). Especially in the USA, the irrepressible economic confidence led to a property boom and intensive speculation in shares. Galbraith marked this short cyclical recovery as a "speculative illusory world" whose existence could be characterized only as short of breath (Galbraith, 2009, p. 35-36). At the end of the nineteen-twenties, the growing prosperity, supported by optimism and speculation fever, reached a size where small investors and companies borrowed more and more money to invest in short-term expected returns on the stocks (Jaeger, 1973, p. 66-67). This optimism and financing were also reflected in technological inventions like radio sets or automobiles (Blaich, 1990, p. 79).

At the end of the nineteen-twenties after the consumer goods market was saturated, the reality came to light. Money was put more in investments than in the needs for replacement. These manufacturing overcapacities turned out to be the result of an excessive trust in the worldwide upswing. The general oversupply of industrial goods exceeded the demand by far and led to price declines (Born, 1967, p. 31). The simultaneous credit-financed speculation fever led to a dangerous combination and problems especially in USA and West-Europe, beginning with first nervousness at stock exchanges and then leading to price slumps. Kindleberger identified the market peak in September 1929, which began to decrease in October, ending on the so-called "Black Thursday” (October 24) with the New York stock exchange panic reactions and start of the economic downturn (Kindleberger, 1973, p. 121122). Europe adjusted the date to Friday 25 after receiving the news of the stock market crash in Europe. The sense of a stock market crisis caused a significant panic selling in Europe as well (Blaich, 1990, p. 7).

\section{Effects and reactions after the outbreak}

A beginning recession connected with slumps on the capital markets (Galbraith, 2009, p. 17; Blaich, 1990, p. 7) quickly led to a depression in December 1929, accompanied by a massive downturn of stock prices in the amount of 15 billion USD (Galbraith, 2009, p. 89). If the index was 191 points at the beginning of 1928, a doubling to 381 points was recorded by September 1929 (Kindleberger, 1973, p. 111), which then dropped to a low in July 1932 reaching only 41 points (Zschaber, 2010, p. 71; James, 2008). These were the first numbers indicating that the USA was hit the most by the crisis. Galbraith characterized this depression as lasting, more or less, ten years, with changing intensities confirmed by the following data: the GDP in 1933 was one third lower than in 1929. It did not achieve the 1929 level until 1937, when it immediately dropped again. Until 1941, the production volume stayed at the level of 1929, but at least the unemployment rate declined below eight million for the first time after the crisis outbreak. Almost thirteen million people were unemployed in 1933, meaning one out of every four Americans. In 1938, one out of five people were still without a job (Galbraith, 2009, p. 207; Economic Indicators, 1953).

While production capacity utilization plummeted, a rise in the number of bankruptcies was evident, as well as increased profit declines in many companies. Reflecting 
the four-year development in the USA from 1929 to 1932, the fall in wholesale prices for agricultural products in particular, weighed $50 \%$ and the decline in total industrial production also nearly 50\% (Junker, 2004, p. 131-132). In connection with the price drop, a credit systemic crisis was revealed as debts had to be settled by lower profits (Rothermund, 1993, p. 40). This lack of money blazed the trail for a banking run and their deposits, leading to a banking collapse. Investors lost confidence and demanded deposits in cash, forcing banks to liquidate loans. From 1929 to 1933, thousands of American banks had to file for bankruptcy (40\% of all banks), which led to a loss of control within the US financial system which was under the influence of international money transactions, and stepped over to the European markets. With successive withdrawal of American capital, the banking crisis in Europe began. Additionally, steps were taken in the form of custom duties and import restrictions in order to save the local products from the outer world (Mußler, 2008). Thereupon, the global trade volume suffered until 1933 a dramatical collapse (Kindleberger, 1973, p. 179-180; League of Nations, 1934, p. 51) as, in addition to the USA, many other countries arranged protectionist measures based on the "Run for your lives" principle, and thus the crisis took a turn for the worse (Junker, 2004, p. 131). The gross national products of the seven leading industrialized economies decreased by 20\% between 1929 and 1932 (Temin \& Voth, 2001), and unemployment figures followed a similar pattern. James elaborated that, during the worst part of the crisis, almost every third employable citizen was unemployed in Germany, and every fourth in Great Britain (James, 1988, p. 24; Mitchell, 1978, p. 67-69, 180-181). After the USA, Germany was second most affected by the crisis and dependent on American (foreign) credits after the First World War. Additionally, there were reparation requirements of the Young Plan which had to be fulfilled. Both marked cash flows amounting to billions that were not offset by goods or services (Blaich, 1990, p. 81-82). With the depletion of domestic finances and the "Run on Germany" by foreign creditors, the banking crisis began in Germany. At the same time, a run took place by the citizens on their savings deposits (Kindleberger, 1973, p. 163-164). To avoid a total bank crash, the government nationalized major banks as the last resort, Dresdner Bank at a rate of 91\%, Commerzbank 70\% and Deutsche Bank 35\% (Born, 1967, p. 167176). James sees the banking crisis and its eruption in the summer of 1931 as the main initiator ofr the transition in the German Great Depression, showing comparable examples and parallels with other European countries. Similar crises happened in Central and Eastern Europe with banking crashes in Austria and Hungary. France was afraid to lose the stability of their banking system after the collapses of the Banque Adam in Boulogne-sur-Mer in November 1930 and the bankruptcy of the Banque Nationale de Credit. In
Italy, the bigger banking crisis was able to be avoided only after the government's intervention (James, 1988, p. 275).

In addition to the banking crisis, other key figures reflecting the German economy in the period reveal a rather straightforward result: a decrease of the national income by almost 40\% from the end of 1928 until 1932. Similar numbers are registered in the area of wages and salaries as well as in trades and industrial production (Wagemann, 1935, p. 50, 95, 176-177; Länderrat des Amerikanischen Besatzungsgebiets, 1949, p. 600). Rationalisation measures in the form of numerous redundancies, closures of banks and rise of unemployment affected over six million people (Wagemann, 1935, p. 16ff.). The beginning of crisis management implemented by the German government included an austerity policy with instruments like tax increases, restrictive monetary policy and public expenditure reductions primarily in the form of reduced civil servants salaries or social benefits (Blaich, 1990, p. 65, 96). Citizens' dissatisfaction with these harsh programs shifted from the economical crisis to a new crisis after, in January 1933, Hitler came to power and paved the national-socialist way in Germany (Hüwe, 2007, p. 46).

Political direction in the US was coloured by the economic and political program "New Deal” initiated in 1933 by the then President Franklin D. Roosevelt. It lasted five years (until 1938) and was characterized in established literature as a road to recovery, marking a simultaneous political turnaround in which "the power of the federal government was expanded”. It consisted of public work projects, stabilizing industrial and agricultural production, and a reform of the financial system, including a regulation of the stock market to prevent events like the 1929 crash (Smith, 2014, p. 2; Soboczynski, 2005).

\section{Crisis of 2007}

\section{Before the outbreak}

The causes of the subprime crisis are manifold and have their origin again, like in the 1930s, in the USA. There are a number of causes which, through their interaction, provoked this crisis. In order to comprehend the complete background, a monocausal point of view will not apply (Elschen \& Lieven, 2009, p. V). In terms of a concomitant framework and conditions of origin, it has to be considered that the concept of optimism is a significant part of the American culture and way of thinking. This includes not only a positive belief but also hopes (Gerbert, 2009), as reflected in the classic "American Dream" and the campaign slogan of the former President Barack Obama “Yes, we can! ” (Mieder, 2009, p. 119). As a result, concerns about the future and livelihood 
were much less frequent in the US than in other countries, as illustrated, among other, by the more permissive consumer behaviour (Czaykowski et al., 2009, p. 43). The savings activities of American households have accounted for a significant decline since the 1980s, the focus was on consumption, which often led to debt (Rickens, 2005, pp. 135-136). With the bursting of the "Internet bubble" in 2000 (Schumann \& Grefe, 2008, p. 90) and the terrible terrorist attacks in 2001, the American economy was on the verge of collapse (Harrison, 2008, p. 79). As a countermeasure, central banks led by Alan Greenspan cut interest rates from $6.5 \%$ to $1 \%$ in 2003 . In a situation with an interest rate level below the rate of inflation, it was quite understandable that every American lent money rather than to save it. So they reacted quite logically to the incentives they had been given. The rate cut allowed credit institutions to provide credit at a low cost, which was extremely well received and resulted in a negative savings rate for the first time in US history. An economist would sum up the situation from an economic perspective in the folowing way: "Economists say real interest rates are negative, that is, interest rates taking into account inflation expectations. That is, anyone who had money in the bank and saved every year lost value. Anyone who lends money, however, made a profit every year, because the interest payable is less than the loss of value.” (Russell, 2008; Münchau, 2008, pp. 6-7). The often already indebted American citizens were therefore not unmotivated to take on these terms and new debts (Rickens, 2005, p. 138). Invitational circumstances prevailed, triggered by tendentially lapidary credit checks, in which the debtors did not necessarily had to show equity capital (Schäfer, 2009, p. 155).

After the economic situation in the USA began to recover and the terror attacks have been processed step by step, the key interest rate from 2004 was raised gradually from 1\% to $5.25 \%$ in June 2006 in order to prevent an inflationary threat. This move also affected the mortgage rates (Bloss et al., 2009, pp. 155-156) and led to an increasing real estate demand. With regard to increased property prices, homeowners felt safe and were not averse to further consumer lending offers. Finance distributors concentrated on low-income "subprime" citizens because of higher interest gains in this expanding segment and sold them as particular investments. These "second-class" loans are secured worse than "normal" real estate loans with the effect that their interest rate is higher. Not only borrowers wanted to benefit from favourable interest rates. Banks and other investors were investing in the booming American real estate market, concretely in financial instruments like mortgage-/asset-backed securities. These mortgage bonds covered with subprime loans offer higher interests but also much higher price-risks (Stroisch et al., 2009, p. 1). Some economists addressed this area critically as a further part that participated in the emergence of the crisis. This trend-like development unfolded in the run-up to the crisis of such magnitude, contrary to the expectations and imagination of all those involved. Many finance economists see their starting point in 2002, when Alan Greenspan explicitly welcomed the introduction of financial instruments like securitizations or Collateralized Debt Obligations (Krassin et al., 2009, pp. 69-72): “These instruments have been used to disperse risk to those willing, and presumably able, to bear it. Indeed, credit decisions as a result are often made contingent on the ability to lay off significant parts of the risk. Such dispersal of risk has contributed greatly to the ability of banks - indeed of the financial system - to weather recent stresses. More generally, the development of these instruments and techniques have led to greater credit availability, to a more efficient allocation of risk and resources, and to stronger financial markets." (Greenspan, 2002). Securitisations like asset-backed securities are defined in general as securities in which original receivables from bank loans, lease and credit card contracts, mortgages or risky bonds are converted into tradable securities with the aim of selling them to interested investors. Here also, financing companies can be interposed and thereby in addition to the investors to a spreading of the credit risk (Braunberger \& Fehr, 2008, p. 200). It should be noted that, in the context of these newer forms of financing, lending processes have been defused in practice (Huth, 2009 p. 49). The original concept of securitization was to better manage and spread the risks associated with lending by outsourcing credit claims to special purpose vehicles. The result was seen after 2007 (Krassin et al., 2009, p. 69-72): “an innovation genie was first let out of the bottle and eventually devoured the system, to the horror of its creators.” More terms such as "the mortgage time bomb" (Tett, 2009), financial hydrogen bombs built on computers by 26-year-old MBA graduates (Krassin et al., 2009, p. 69-72) were the order of the day.

The low level of interest rates combined with the excessive lending practice finally led to a huge increase in real estate sales since the turn of the millennium, which reached its climax in 2006 and then declined again thereafter (National Association of Realtors, 2014). The borrowers were now exposed to very high repayments and interest rates, as the initially favorable interest rates from the loan relationship based on the development of the capital market at that time only existed in the initial phase. The initial interest rates had long since been overtaken by the US Federal Reserve's interest rates. The variable and thus unpredictable interest rates are now revealed to be high and put into effect risk factor. Particular problems presented citizens who took a real estate loan and left the property as collateral with the bank. After the non-payment of the credit installments, the banks used the deposited as a pledge houses and initiated, inter alia, forced sales. Over time, these documents have become more dynamic and have lowered real estate prices. The decline in house prices was so dramatic that the proceeds were unable 
to pay off the loan. The indebted borrower not only had to deal with the situation of a home loss, but also retained his debtor status, as part of his real estate loan was not paid. The high default rate of the so-called subprime loans created an oversupply in the real estate market and, correspondingly, further price drops (Bartmann et al., 2008, p. 15).

Just before the crash in 2007, dramatic events have turned over as payment defaults of borrowers led directly to the crisis. The resulting economic consequences were evidenced by high depreciations of companies to bankruptcy filings, in particular American real estate banks proclaimed (Bischoff, 2008, p. 11.). In 2007, a number of German banks had to deal with these consequences, caused by verse speculation on the financial market and depreciations in their balance sheets in billions (Strotz, 2007). Investors all over the world lost within an extremely short time billions (Salzman, 2018). The citizens, who were heavily indebted by the real estate loans, now had to put up with the restriction of other consumer activities. The resulting reduction in demand for all types of products experienced their highest profile in the automotive sector. The acquisition of an automobile on installment credit was expected to decline sharply as a result (Berndt, 2009, p. 8; Hierschel, 2009, p. 91). In addition to the strained financing situation on the part of the customers, the hitherto increased oil price also provided a tangible dampener in the demand situation of automobile manufacturers (Dill \& Lieven, 2009, p. 205). Global automakers such as Toyota, Chrysler or General Motors suddenly fell into a crisis situation - in the subsequent step, the market for accessories was vulnerable (Henkel, 2009, p. 150).

In summary, it can be shown that the determinants of global financial crisis from the US mortgage market are presentable. Since the real estate market in the US has been a lucrative investment for a decade and promised high returns through investment in financial instruments as a result of the "real estate boom”, German and other European banks have also found this market for themselves. Despite known and potential risks, many bank advisors have been encouraging their clients or retail investors to invest their capital in the US mortgage market. As a result, the crisis, which was initialized as a subprime crisis in the USA, was able to expand into the international capital markets (Huth, 2009, p. 49).

\section{Effects and reactions after the outbreak}

At first glance, the economic consequences of the current crisis were no less serious. At the latest with the insolvency report of the formerly powerful investment bank Lehman Brothers on 15 September 2008 in the USA, the financial crisis got into more than a purely commercialized position. Only one day later, the rescue of the world's largest insurance company American International Group (AIG) by state-run bridging loans amounting to US \$ 85 billion was at the centre of economic activity. Other financial institutions escaped such fate only with great difficulty or, alternatively, got involved in acquisition processes of competing companies (Brunner, 2009, p. 48). The business journalist Ulrich Schäfer attested to the situation a degenerate drama and expresses himself openly critically in a capitalistic context: "The bosses of America's leading banks hit the 'Mother of All Slaughterers' tonight. They're trying to save Wall Street this Sunday. The heart of capitalism. It's about the fate of Lehman Brothers, one of the five big investment houses. And it's about the fate of all the big banks, the future of the world financial system. For almost a year and a half, everyone believes the financial crisis is an American problem. And the USA would have to solve this. But when the American investment bank Lehman Brothers goes bankrupt on September 15, 2008, a huge hurricane breaks out, which affects the entire globe within a few weeks.” A summary and conclusion of his statements allows speculation space for a crisis repeat after almost 80 years, in Wall Street -as the centerpiece of global capitalism - was initially exposed in early 2007 to the insolvency of numerous homeowners in the US real estate market and degenerated into a financial market crisis, closely followed by the banking crisis. The climax in autumn 2008 was the outbreak of the second finance world crisis, whose outflow was felt by the entire global economy as a result (Schäfer, 2009, p. 187-188).

The economic impact of the financial crisis was impressively visualized in the October 15, 2008 news: the USA raised $\$ 455$ billion in the largest budget deficit in its history. The economic situation, expenditures on the labor market and support on the financial market have left their mark (dpa/ Reuters, 2008). Ultimately, the crisis became a global affair, regardless of whether the states concerned were in favour of being classified as an industrial, emerging or developing country (Sinn, 2009, p. 52-53).

At the beginning of the crisis, there was still some optimism in Germany to be able to withstand the crisis. In his government statement of 25 September, 2009, the former Federal Minister of Finance Peer Steinbrück was still inclined to attribute a relative triviality to the situation in Germany: "Overall, it shows that the German 3-pillar system is relatively robust in international comparison. The German supervisory authority, BaFin, is convinced that the increased risk-bearing capacity of German institutions in recent years is sufficient to offset the losses and to ensure the safety of private savings. ... What the US is now doing on a massive scale with the US $\$ 700$ billion rescue program is something that we did in Germany quite deliberately for affected banks such as IKB, Sachsen LB, Bayern LB and West LB months before to have. Therefore, and because the conditions are 
different for us, a similar program in Germany or Europe is neither necessary nor useful. It is still true that the financial market crisis is above all an American problem!” (Steinbrück, 2008). Schäfer has falsifyingly positioned himself to Steinbrück's statements in this way: "If only it were so. That same evening Steinbrück squats with Germany's most important bankers. A small circle that knows how to report something disturbing. ... They warn that a major German bank is in danger: Hypo Real Estate, a powerful real estate financier and one of the key players in a boring market, namely mortgage bonds. For days, Hypo Real Estate has been struggling to get money from other banks - without much success. ... Steinbrück and his followers quickly realize that there is not just a small problem here, but a very big one. The Minister of Finance informed Federal Chancellor Angela Merkel. ,Hypo Real Estate threatened to literally dry out,' he says later. Stay 48 hours to get fresh money. Otherwise, BaFin's financial supervision would have to close down the bank ... if ... HRE could no longer service its business." The reaction and intervention of the Federal Government then took place on 29 September, 2008 in the form of guarantees and transfer payments in the tens of billions (Schäfer, 2009, p. 203.). The stronger perception of crises among the citizens - especially due to the intensity of the media coverage - led to increased saving behaviour as well as a lack of consumption and had a suboptimal impact on the economy (Brunner, 2009, p. 51). The search for adequate solutions to overcome the crisis and its consequences was accompanied by ever-increasing discussions between experts (Krugman, 2009, p. 212).

The course of the crisis took its toll on the one hand through the increased number of personal bankruptcies (Schüddemage, 2011; Elschen \& Lieven, 2009, p. VIII) and on the other hand by writedowns amounting to billions of dollars of the big banks, which meant that their balance sheets had a considerable impact on earnings. In the fall of 2007, the British building society Northern Rock first served as a victim of the global financial crisis and subsequently had to be nationalized. Numerous major American banks such as Bear Stearns or Morgan Stanley were not defensible, especially triggered by previous existence-threatening depreciation (Otte, 2009, p. 218-219). Bear Stearns' rescue in March 2008 was provided by the acquisition of investment bank JP Morgan Chase, which was accompanied by the strong support of the US Federal Reserve in the form of a \$30 billion guarantee. The state intervention allowed for a brief relaxation in the financial market and left the impression that the American government would not abandon a bank (Münchau, 2008, p. 40-41).

However, alarming signals became visible from the second quarter of 2008 onwards due to the development of the unemployment rate in the US, as it soared from initially 5\% within one year to almost 10\% (Dill \& Lieven, 2009, p. 213). This development has also been preceded by a general turbulence on the stock markets, which, since the terrorist attacks in 2001 at the beginning of 2008, has slipped into the highest price collapse zone. Although the subsequent US\$150 billion first-quarter US economic stimulus package served as a temporary reassurance, it was not powerful enough to prevent the events after the second quarter. The two largest US mortgage banks, Freddie Mac and Fannie Mae, were unable to avoid the umbrella of sovereignty, as their viability was not secured without capital support, and their stock prices registered a near-50\% decline. The bankruptcy filing of Lehman Brothers in September 2008, the fourth largest investment bank in the US, opened up global stock market concerns and pessimism among banks and intensified the global financial crisis. Even the DAX was not without consequences by his loss of points to less than 6000. A punctual overshadowing of the events caused the breakdown transfer of the German Kreditanstalt für Wiederaufbau (KfW) on 15 September, 2008, whose monetary transfer despite the above-mentioned insolvency report amounted to more than 300 million euros and thus formed the basis for further losses. On the same day - the so-called "Black Monday" (Hellerforth, 2009, p. 142) - another takeover in the major US banking industry emerged through the acquisition of Merrill Lynch by Bank of America for $\$ 50$ billion (Elschen \& Lieven, 2009, p. 368). The year 2008 may go down in history as the year of the great bank dying, as no fewer than 83 banks worldwide have disappeared or been nationalized by bankruptcies and takeovers this year. Despite a collective interest rate cut by the six leading central banks (ECB, Fed and the British, Canadian, Swedish and Swiss central banks) in October 2008, the Dow Jones Index and the DAX saw a continued decline on the international financial markets this month alone a loss of double-digit percentage points (Sinn, 2009, p. 65-66). Another bad news was caused by the AIG, which in the meantime kept a US\$100 billion government loan from illiquidity (Hässig, 2009, p. 186). The beginning of 2009 marked figuratively the immense effects of the recession on the key figures of the American labor market, which recorded the highest unemployment rate in 15 years. This negative side effect did not stop even on German territory and generated an increase in the number of unemployed again in this country over the three million mark (Hellerforth, 2009, p. 155).

The 13th of November 2008 sealed the official announcement day, when the public heard the news that Germany was in recession for the first time in five years. The Federal Statistical Office confirmed this statement with the help of the available data that the German economy reported declining economic output for two quarters in a row (Jackisch, 2008). Even in Germany, the banking sector was threatened by the financial distress of numerous credit institutions, in which 
the state-owned regional banks, in particular, participated in the preliminary stages of the crisis event by investing in sub-prime securities of various US mortgage lenders (Hader et al., 2009, p. 148).

As the first German institute, the Mittelstandsbank IKB had succumbed to the maelstrom of the US real estate crisis and found itself in an existential emergency that affected the crisis with an expansion towards Europe. Only three weeks later, Sachsen LB suffered a comparable fate due to bad investments in the American real estate market, which could only be obstructed by a guarantee loan from the Free State of Saxony of over 17 billion euros. Subsequently, the bank was sold to Landesbank Baden-Württemberg. Bayern LB and West LB also faced losses in the billions due to speculative credit derivatives (Schäfer, 2009, p. 170-171, 181), while Deutsche Bank recorded the first quarterly loss in five years in 2008 with a loss of $€ 141$ million (Kazim, 2008). The state-owned KfW banking group also recorded a loss for the first three quarters of almost 1.8 billion euros, while Citigroup proclaimed austerity measures in the form of 53,000 job cuts. Not only was the banking sector exposed to such repercussions, but also in the automotive sector, and in particular at Opel, a request for state aid was made at the end of 2008 (tagesschau.de, 2008). This emergency was preceded by industry-specific declines in exports and production in the amount of 20 percent, which were made public by the announcement of the end-of-year figures for 2008 of German carmakers. Significant for this branch of the economy was the arrangement of short-time working for tens of thousands of employees. In addition to the car manufacturers, the decline in incoming orders and exports was also noticeable at the beginning of 2009 for the other German companies (tagesschau.de, 2009). At the beginning of June 2009, two other large corporations also played a key role in the German news landscape: Opel parent company General Motors and retailer Arcandor. The first one announced its insolvency on June 1 and the second on June 9 (Handelsblatt, 2009).

The macroeconomic perspective quickly reveals that the application of the instruments has focused in particular on a gradual reduction in central bank interest rates, fiscal policy instruments such as government guarantee transfers and extended credit facilities.

\section{Discussion on Crisis Endings}

The previous work on the comparatistics of both crises has certainly led to the presentation of an abundance of opinions with multi-faceted possibilities of analysis to give a character to the characteristic features of both crises. These findings need to be channeled, also against the background that crises must sooner or later come to a conclusion or at least should. This is exactly where the current chapter opens. It is important to repeat or find out from the examination context certain nuances for the evaluation of crisis ends that others have not or only selectively considered.

Accordingly, the focus of the investigation lies both in the exploration of the respective crisis end phase and the inspection of comparability criteria of both, combined with the question of whether the term "crisis end" is at all entitled to its terminology. The determination parameters can follow various sub-questions or discussions. So one could question, especially in relation to Germany, whether in the 30s world economic crisis can only speak of a delay in a political crisis due to the dictatorship of Hitler or whether it is a relocation process in the Second World War. An initial nod to the newer or latest crisis reflects the current research situation and presents itself as highly questionable as to whether it is over. The turnaround by the short-term reaction of the policy manifested itself as promising and promoted a successful course, the events around the euro crisis led but a shadowy existence, so that the question itself nominated as presentable, whether the crisis was only deferred and overflowed into a community currency crisis. The comparison of the two ends of the crisis ultimately also allows access to the philosophical discussion according to which the above questions are also explored in the same way.

A first ubiquitous thesis was that a "ruthless gang" of crooks has the financial world in their hands and that "they would rather get caught up in a severe economic crisis than to forego a chance to win”, additionally without their activities the "recent upheaval" on the capital market would have spared us. For the economic historian Werner Plumpe, these statements bear more doubt than certainty and condense into a kind of fallacy. This finds particularly good breeding ground if one takes the past into widespread remembrance, in which social turbulence has rocked to economic crises and relaxed again. Because economic crises are, as Plumpe convincingly states, "among to the recurring, formative events of history; their significance has been and is often so great that they radiate far beyond the economic sphere and cause serious political and social problems.” By implication, this means that economic crises do not legitimize themselves as a new experience (Plumpe, 2011, p. 7-8).

Looking back to earlier eras, comparable events were even handed down in the Old Testament with the Joseph story of the seven lean and the seven fat years, in which the biblical formula "seven good episodes always seven bad years" became regular. Thus, the "fat" years were accompanied in regular sequence by subsidiary climatic characteristics that had a beneficial effect on the harvest, while these stayed in the "lean" years and were flanked by hunger and distress 
(Kulke, 2011). Fluctuations in crops also served in the wake of the history of Old Europe as an initiator of crisis states, undermined by economic and social hardship. Despite overcoming and increasing agricultural productivity since the 19th century, these crises did not end, as the economy's development has since been subject to rolling economic disruption. One should, however, avoid damaging reality and dismantling and polarizing the fluctuations of harvests and the economy as well-known plagues of society. In addition, there are speculation crises, which also represent no new phenomenon, but at least allow driving new research approaches (Plumpe, 2011, p. 7). Be it the then "tulip scam" in the Netherlands in the 1630s, where, according to Weber, to lighten up this "fraud" tulips as luxury and speculation junk “fantasy prices” achieved (Weber, 2011, p. 258-259), the Mississippi speculation about John Law (Rothengatter \& Schaffer, 2006, p. 204) or the same time "South Sea Soap Bubbles” in England from 1718-1720 (Born, 1982, p. 131132). In addition to a further stacking of speculative bubbles of the 19th, 20th and 21st centuries -e.g. the Australian banking crisis of 1893 or the Scandinavian Crises 19841992 (Schnabel \& Brunnermeier, 2014, p. 23) - they mark an almost inescapable abundance of crisis-like downturns, which to this day more or less repeat. On the one hand, this admiration requires that such crisis processes repeatedly manage to iterate as "obviously a normal part of the economic process” (Plumpe, 2011, p. 8). For others, its proportions are an indicator of political apathy, whether and to what extent reactions of the respective governments have been pronounced (Schnabel and Brunnermeier, 2014, p. 23).

In addition to the actual economic crises, it should be permissible to draw up a series of thoughts in which, due to the topical nature of the issue, state bankruptcies are also profiled as normative crisis drivers, even if these are not necessarily cataloged in the context of economic crises in the narrower sense (Plumpe, 2011, p. 8). If one obeys the results of the investigations of the American economists Carmen M. Reinhart and Kenneth S. Rogoff, de facto longterm financial difficulties and over-indebtedness of states as well as resulting difficulties qualify as multiple crisis producers of the last centuries (Reinhart \& Rogoff, 2009, p. xxvi-xxx). When mentioning the history of sovereign debt crises, however, one should not get the impression that these events are to be regarded as usus of national careers. By way of example, Reinhart and Rogoff cite "Australia and New Zealand, Canada, Denmark, Thailand and the USA" as states that have been able to prevent foreign debt crises so far in their history (Reinhart \& Rogoff, 2009, p. xxx).

In summary, based on the previous crisis reflections of the previous century, it can therefore be postulated that they can be roughly sequenced over time. The crises of the "pre-modern” world are characteristically interpreted as agrarian and food crises, while at the beginning of the 19th century, with the infiltration of modern capitalism, bankruptcy and the appearance and raging of speculative bubbles have serious consequences for the overall economy. The transition from climate and weather as crisis-determining factors of the "premodern" time to rhythmic economic cycles, which have not infrequently caused crisis by speculative bubbles on the capital markets, reveals the crude historical subdivision of antiquarian and novel crises (Plumpe, 2011, p. 9).

\section{Final Conclusions}

\section{Findings}

According to the contributions from the representatives of economics, political science and political economy, at least ten parallels between the two main crises can be found:

1. Both crises are known to set out on the world's largest financial market - the USA (Jahnke, 2009, p. 9).

2. In both cases, a recession accompanied the price falls on the capital market, from which "a long-lasting depression - comparable to the global economic crisis in the first third of the 20th century - was developing” (Bischoff, 2009, p. 27-28; Hollnagel, 2009, p. 41; Galbraith, 2009, p. 9-10, 17).

3. The outbreak of both crises was preceded by a real estate boom - regarding the first crisis, it was the so-called Florida crisis and property boom of the mid-twenties (Jahnke, 2009, p. 9; Galbraith, 2009, p. 35-36).

4. Both crises were characterized by high levels of borrowers and investors' indebtedness (Braunberger and Fehr, 2008, p. 9; Mußler, 2008, p. 81).

5. In both crises, overproductions emerged in the consumer goods market (Köhler, 2009, p. 68; Glebe, 2008, p. 80), in the newer crisis especially noticeable in the automotive sector (Kirchhof, 2009, p. 8).

6. In both crises, the share of corporate payouts in relation to US economic output peaked up to gloss values of $5 \%$ (Jahnke, 2009, p. 23).

7. The renowned economist John Kenneth Galbraith indicated for both crises an unequal distribution of income and wealth in the USA. In 1929, five percent of all households registered approximately one third of the whole national income; in 2004, it was six percent of all households who registered the same dimension (Galbraith, 2009, p. 13).

8. Banks were hit by the most destructive consequences of the crisis: "The banking crisis as the core of the global financial and economic crisis.” Countermeasures were essential here (Paul \& Kösters, 2009, p. 41-42; Soros 2009, p. 25-26). 
9. Both crises caused a jolt in the entire world economy (Zeise, 2009, p. 11).

10. In both crises, specialized financial instruments were responsible for tightening the stock market, after 2000 for example "Hedge-Fonds", "Private Equity” or asset backed securities, before 1929 "Investment-Trusts" (Galbraith, 2009, p. 10), as a result of which, “a new service industry has emerged, the financial investors. They took ... mainly three strategies:

- They engaged in risky speculative transactions in which they use large amounts of credit, ...

- They change company policy and focus on the short-term realization of high returns (shareholder value control), ...

- They put a lot of pressure on states (governments and parliaments) where they invest to enforce tax cuts and privatizations” (Huffschmid, 2009, p. 109-110).

\section{Summary and outlook}

Initial findings have shown that more parallels between the two crises could be worked out than many expected (compare 4.1). Whether the elaborated enumeration of the preceding parallels - resulting from the statements of various disciplinary representatives - gives sufficient affirmation in order to be regarded as prevailing and conclusive, doubt may be expressed. The political scientist Uwe Andersen reads a first relativization of the apparent parallels: "In the dimension of both the systemic threat and the real world impact, the current global economic crisis is comparable only to the global economic crisis of 1929, even if there are important differences (crisis origins, reactions and time course) are to be considered. ... Even the answer to the central question of whether the current global economic crisis is a systemic crisis must be differentiated and depends to a large extent on one's own basic perspective” (Andersen, 2009, p. 5). In addition, there were other factors that spoke against comparable effects on the crisis as in the 1930s. For example, in times of the Great Depression, existing customs walls for transnational interactions were constructed as an incommoded hurdle faced with imports and exports. In times of globalization and the increasingly interdependent markets, such "disruptive factors" are more and more depleted (Kindleberger, 1973, p. 77.; Plumpe, 1984, p. 56-57; Hoffmann, 1965, p. 150; Junker, 2004, p. 131; Svennilson, 1954, p. 292, 304-305). Not only that, compared to 1929, governments are increasingly cultivating closer and more cooperative relations. The exemplary existence of international organizations such as the International Monetary Fund, which was founded together with the World Bank to promote global monetary policy cooperation and the expansion of world trade after the Second World War in 1945, supports this thesis. Namely that protectionist constructs such as the then foreclosure of isolated countries had long since become the obsolete model and after all brought the states nearer (Woyke, 1985, p. 25).

At the same time, the political framework conditions and effects of crises in both epochs are structurally only partially comparable. Although in both events displeasure in the population and the mistrust in politics are recognizable, the political structures of the present and the past are still too divergent. Today's democratic structures are more stable than they were before the Second World War, and thus gave the citizens realistic hopes for a better situation in their own country, so - as a special example - that Germany was spared a similar political catastrophe as at the end of the Weimar Republic. Despite these anatomical peculiarities, parallels can be found in terms of crisis management to some extent, which were particularly related to nationalization. In both eras, conspicuous state commitments were observed here, which led to abundant support payments for bank bailouts and were not uncritically seen. The previous work on the comparatistics of both crises has certainly led to the presentation of an abundance of opinions with multi-faceted possibilities of analysis to give character to the characteristic features of both crises. These findings need to be placed also against the background that crises contain, sooner or later, a conclusion or at least should.

Another cognitive criterion is revealed in the observed development flows of said crisis events. Their progress also saw a loss of their apocalyptic dimensions. Instead, the phenomenon of the economic crisis into a cyclical construction with "upswing, boom, recession and depression" shaped, which according to Plumpe - who also refers to the views of Karl Marx and Clement Juglar - "no longer followed external irritations, but apparently a kind of inner lawfulness of capitalist development” (Plumpe, 2011, p. 9).

Surely, with an all-round view of the whole investigation, it appears that in the coming years there will be greater sensitivity on the financial markets and that the policy of observation should be sharpened. A look at the recent past has shown, on the one hand, how vulnerable the current financial system is and, on the other hand, what new and complex financial instruments can do - combined with a low interest rate policy. Here, it is important to learn from past mistakes so that we will not face a new crisis soon. Among other things, this should be due to the fact that, with the issuance of costly and extensive stimulus packages, the new indebtedness of the respective states has grown into a dimension whose numerology not only creates a dizzying character for the inclined reader, but also imposes inherited burdens on succeeding generations, which remain as elementary regulatory criticisms of the recent crisis and which will confront them with challenging tasks in the future. 


\section{References}

Andersen, U. (2009). Einführung. Althammer, Jörg/Altvater, Elmar/Andersen, Uwe/Breit, Gotthard/Kösters, Wim/Paul, Stephan/ Zimmermann, Hubertus. Weltwirtschaftskrise - eine Systemkrise? Vienna.

Bartmann, P., Buhl, H. U., \& Hertel, M. (2009). Ursachen und Auswirkungen der Subprimekrise; discussion paper WI-233. Augsburg. https:// doi.org/10.1007/s00287-009-0328-7

Beller, J., \& Kipke, R. (2006). Einführung in die Politikwissenschaft. Munich https://doi.org/10.1524/9783486599183

Berg-Schlosser, D., \& Müller-Rommel, F. (2003). Vergleichende Politikwissenschaft. Wiesbaden. https://doi.org/10.1007/978-3-322$86382-9$

Berndt, E. (2009). Toyota in der Krise - Von den Widersprüchen und Grenzen des Status Quo. Leipzig.

Bischoff, J. (2008). Globale Finanzkrise - Über Vermögensblasen, Realökonomie, und die „neue Fesselung“des Kapitals. Hamburg.

Bischoff, J. (2009). Globale Wirtschaftskrise - Deutungsansätze und Bausteine zur theoretischen Einordnung. Altvater, Elmar/Bischoff, Joachim/ Hickel, Rudolf/Hirschel, Dierk/Huffschmid, Jörg/Zinn, Karl Georg (Eds.). Krisen Analysen. Hamburg.

Blaich, F. (1990). Der schwarze Freitag-Inflation und Wirtschaftskrise. Munich.

Bloch, M. (2000). Aus der Werkstatt des Historikers. Frankfurt a. M.

Bloss, M., Ernst, D., Häcker, J., \& Eil, N. (2009). Von der Subprime-Krise zur Finanzkrise - Immobilienblase: Ursachen, Auswirkungen, Handlungsempfehlungen. Munich. https://doi.org/10.1524/9783486592436

Braunberger, G., Fehr, B. (Eds.). (2008). Crash - Finanzkrisen gestern und heute. Frankfurt a. M.

Brunner, J. (2009). Finanzkrise 2008 - Wie es dazu kam und mit welchen Folgen wir rechnen müssen!. Buchkirchen.

Born, K.-E. (1967). Die deutsche Bankenkrise 1931 - Finanzen und Politik. Munich.

Born, K.-E. (1982). Wirtschaftskrisen.Albers, Willi (Ed.): Handwörterbuch der Wirtschaftswissenschaft, Volume 9. Stuttgart/Tübingen/Göttingen.

Bundesministerium für Wirtschaft und Technologie (Federal Ministry for Economics and Technology). (2010). Konjunktur- und wachstumspolitische Maßnahmen der Bundesregierung in der Wirtschafts- und Finanzkrise. Retrieved from http://www.bmwi.de/BMWi/ Redaktion/PDF/J-L/konjunktur-und-wachstumspolitische-ma_C3_9Fnahmen-bundesregierung,property=pdf,bereich=bmwi2012,sprache $=$ de, $r w b=$ true.pdf

Chorafas, D. N. (2009). Financial Boom and Gloom - The Credit and Banking Crisis of 2007-2009 and Beyond. Houndmills, Basingstoke, Hampshire/New York.

Czaykowski, M., Wink, K., Theiselmann, T., \& Gehring, H. (2009). Konsumverhalten und Hypothekenmarkt in den USA. Elschen, Rainer/Lieven, Theo (Eds.). Der Werdegang der Krise - Von der Subprime- zur Systemkrise. Wiesbaden. https://doi.org/10.1007/978-3-8349-8547-7_2

Dill, A., \& Lieven, T. (2009). Folgen der Krise für die internationale Realwirtschaft. Elschen, Rainer/Lieven, Theo (Eds.). Der Werdegang der Krise - Von der Subprime- zur Systemkrise. Wiesbaden. https://doi.org/10.1007/978-3-8349-8547-7_9

Dpa/Reuters. (2008). USA häufen Rekorddefizit an. Retrieved from stern.de (15 October). Accessed July 18, 2019, http://www.stern.de/ wirtschaft/news/finanzkrise-usa-haeufen-rekorddefizit-an-642314.html

Economic Indicators: Historical and Descriptive Supplement. Joint Committee on the Economic Report. (1953). Washington.

Elschen, R., \& Lieven, T.(Eds..).(2009).Der Werdegang der Krise -Von der Subprime-zur Systemkrise.Wiesbaden. https://doi.org/10.1007/978$3-8349-8547-7$

Galbraith, J. K.. (2009). Der grosse Crash 1929 - Ursachen, Verlauf, Folgen. Munich.

Gerbert, F. (2009). Pessimisten blicken besser durch. Focus Online (14 March). Retrieved from http://www.focus.de/wissen/wissenschaft/ mensch/finanzkrise-pessimisten-blicken-besser-durch_aid_380239.html

Glebe, D. (2008). Die globale Finanzkrise - Alle Informationen zur Wirtschaftskrise 2007-2009, dazu Geschichte und umfassendes Gesamtwissen zu den bisherigen Finanzkrisen dieser Welt. Ursachen, Auswirkungen, Reaktionen. Wuppertal.

Greenspan, A. (October 7, 2002). The Annual Convention of the American Bankers Association. Phoenix, Arizona.

Hader, J., Bryazgin, K., \& Lieven, T. (2009). Folgen der Krise für die internationale Finanzwirtschaft. Elschen, Rainer/Lieven, Theo (Eds.). Der Werdegang der Krise. Wiesbaden. https://doi.org/10.1007/978-3-8349-8547-7_7

Hässig, L. (2009). Der UBS-Crash-Wie eine Großbank Milliarden verspielte. Hamburg.

Harrison; Fred. (2008). Wirtschaft Krise 2010 - Wie die Immobilienblase die Wirtschaft in die Krise stürzt. Weinheim.

Hellerforth, M. (2009). Die globale Finanzmarktkrise - Ursachen und Auswirkungen auf die Immobilien- und Realwirtschaft. Hamburg.

Henkel, H.-O. (2009). Die Abwracker - Wie Zocker und Politiker unsere Zukunft verspielen. Munich.

Hierschel, D. (2009). Nach der Krise ist vor der Krise. Altvater, Elmar/Bischoff, Joachim/ Hickel, Rudolf/Hirschel, Dierk/Huffschmid, Jörg/ Zinn, Karl Georg (Eds.). Krisen Analysen. Hamburg.

Hoffmann, W. G. (1965). Das Wachstum der deutschen Wirtschaft seit der Mitte des 19. Jahrhunderts. Enzyklopädie der Rechts- und Staatswissenschaft. Berlin/ Heidelberg/New York. https://doi.org/10.1007/978-3-642-86088-1

Hollnagel, B. (2009). Der Markt hat immer Recht - Die Finanzkrisen und die Lehren daraus. Vienna.

Hüwe, J. (2007). Mit absurder Geldpolitik in die Deflation und zum Ende der Weimarer Demokratie. Retrieved from www.zeitschrift-humanwirtschaft.de (March, 2007), (pp. 46-48).

Huffschmid, J. (2009). Europäische Perspektiven im Kampf gegen die Wirtschafts- und Finanzkrise. Altvater, Elmar/Bischoff, Joachim/ Hickel, Rudolf/Hirschel, Dierk/Huffschmid, Jörg/Zinn, Karl Georg (Eds.). Krisen Analysen. Hamburg. 
Huth, T. (2009). Aggressives Marketing von Banken und Finanzvermittlern. Elschen, Rainer/Lieven, Theo (Eds.). Der Werdegang der Krise. Wiesbaden. https://doi.org/10.1007/978-3-8349-8547-7_3

Jackisch, K. R. (2008). Rezession in Deutschland ist amtlich. Retrieved from tagesschau.de (13 November). Retrieved from http://www. tagesschau.de/wirtschaft/bip104.html

Jaeger, H. (1973). Geschichte der amerikanischen Wirtschaft im 20. Jahrhundert, Wiesbaden.

Jahnke, J. (2009). Die zweite Große Depression - Wo die Krise herkommt, Wo sie hinführt, Was tun? Aachen.

Jahnke, J. (2008). Weltwirtschaftskrise II - Eine komplette Analyse von Entstehungsgründen und Ausmaß der globalen Krise. Aachen.

James, H. (1986). The German Slump; Oxford University Press; (1988). German edition: Deutschland in der Weltwirtschaftskrise $1924-1936$. Stuttgart.

James, H. (2008). Das amerikanische Trauma (3 April). Die Zeit. Retrieved from http://www.zeit.de/2008/15/Harold-James-1929.

Junker, D. (2004). Weltwirtschaftskrise, New Deal, Zweiter Weltkrieg, 1929-1945.

Loeffelholz, Hans Dietrich/Lösche, Peter. Länderbericht USA: Geschichte, Politik, Wirtschaft, Gesellschaft, Kultur. (pp. 129-152).

Kazim, H. (2008). Immobilienkrise: Deutsche Bank meldet erstmals seit fünf Jahren Verlust. Spiegel Online (29 April). Retrieved from http:// www.spiegel.de/wirtschaft/immobilienkrise-deutsche-bank-meldet-erstmals-seit-fuenf-jahren-verlust-a-550298.html

Kindleberger, C. (1973). Die Weltwirtschaftskrise 1929-1939. Munich.

Kirchhof, P. (2009). Rückbesinnung auf ein Grundrecht - Eigentum als Schule von Freiheit und Risik. Depenheuer, Otto (Ed.). Eigentumsverfassung und Finanzkrise. Berlin/Heidelberg. https://doi.org/10.1007/978-3-642-00230-4_3

Köhler, W. (2009). Der Crash 2009 - Die neue Weltwirtschaftskrise. Murnau.

Krassin, A., Yen Tran, T. M., \& Lieven T. (2009). Asset Backed Securities (ABS) und ihr Einfluss auf die Entwicklung der Finanzkrise. Elschen, Rainer/Lieven, Theo (Eds.). Der Werdegang der Krise. Wiesbaden. https://doi.org/10.1007/978-3-8349-8547-7_4

Krugman, P. (2009). Die neue Weltwirtschaftskrise. Frankfurt/New York (translated edition).

Kulke,U.(2011).Fette Jahre, magere Jahre.DIE WELT (7August). Retrieved from http://www.welt.de/print/wams/vermischtes/article13530621/ Fette-Jahre-magere-Jahre.html

Länderrat des Amerikanischen Besatzungsgebiets (Ed.). (1949). Statistisches Handbuch von Deutschland 1928-1944. Munich.

League of Nations, Monthly Bulletin of Statistics. (February 1934).

Mieder, W. (2009). Yes We Can - Barack Obama's Proverbial Rhetoric. New York.

Mitchell, B. R. (1978). European Historical Statistics 1750-1970. London.

Münchau, W. (2008). Kernschmelze im Finanzsystem. Munich. https://doi.org/10.3139/9783446419506

Mußler, H. (2008). Der Börsenkrach von 1929 beendet abrupt die goldenen Zwanziger. FAZ.Net (27 March). Retrieved from http://www.faz. net/aktuell/finanzen/fonds-mehr/historische-finanzkrisen-amerika-1929-der-boersenkrach-von-1929-beendet-abrupt-die-goldenen-zwanziger-1283757.html

Mußler, H. (2008). Der Börsenkrach von 1929. Braunberger, Gerald/Fehr, Benedikt (Eds.). Crash - Finanzkrisen gestern und heute. Frankfurt a. M.

National Association of Realtors. Markt-Daten.de. Wirtschaftsindikatoren (economic indicators) - Übersicht (chart), especially: Immobilienmarkt (real estate market). Retrieved from http://www.markt-daten.de/research/indikatoren/index.htm.

Nohlen, D. (1994). Vergleichende Methode. Kriz, Jürgen/Nohlen, Dieter/Schultze, Rainer-Olaf (Eds.). Lexikon der Politik volume 2 Politikwissenschaftliche Methoden. Munich.

Otte, M. (2009). Der Crash kommt - Die neue Weltwirtschaftskrise und was Sie jetzt tun können. Berlin.

Paul, S., Kösters, W. (2009). Die Bankenkrise als Kern der weltweiten Finanz- und Wirtschaftskrise. Althammer, Jörg/Altvater, Elmar/Andersen, Uwe/Breit, Gotthard/Kösters, Wim/Paul, Stephan/Zimmermann, Hubertus. Weltwirtschaftskrise - eine Systemkrise? Vienna.

Plumpe, W. (2011). Wirtschaftskrisen - Geschichte und Gegenwart. Munich.

Plumpe, G. (1984). Wirtschaftskrise, Wirtschaftspolitik und Nationalsozialismus. Malettke, Klaus (Ed.). Der Nationalsozialismus an die Macht. Göttingen.

Rattner, J., \& Danzer, G. (2007). Politik und Psychoanalyse - Plädoyer für ein Leben in Freiheit, Vernunft und Frieden. Würzburg.

Reinhart, C. M., \& Rogoff, K. S. (2009). This time is different - Eight Centuries of Financial Folly. Princeton. https://doi.org/10.2307/j.ctvcm4gqx

Rickens, C. (2005). Die unersättliche Nation. Manager Magazin, 35(7), 134-142.

Rothengatter, W., \& Schaffer, A. (2006). Makro Kompakt - Grundzüge der Makroökonomik. Heidelberg.

Rothermund, D. (1993). Die Welt in der Weltwirtschaftskrise 1929-1929. Münster - Hamburg.

Russell, K. (2018). Rates for the Seventh Time in Three Years. New York Times, 13 June.

Salzman, A. (2018). How the Financial Crisis Still Affects Investors. Barron's Magazine (July 4). Retrieved from https://www.barrons.com/ articles/how-the-financial-crisisstill-affects-investors-1536361852.

Schäfer, U. (2009). Der Crash des Kapitalismus - Warum die entfesselte Marktwirtschaft scheiterte. Frankfurt/Main.

Schmidt, M. G. (1988). Einführung. Schmidt, Manfred G. (Ed.) Staatstätigkeit. International und historisch vergleichende Analysen. Politische Vierteljahresschrift Sonderheft, 19. https://doi.org/10.1007/978-3-322-83620-5_1

Schnabel, I., \& Brunnermeier, M. K. Frankfurt 2014. Retrieved from https://www.ifk-cfs.de/fileadmin/downloads/Media_Lounge/News/ Schnabel_presentation.pdf. 
Schüddemage, A. (2011). Finanzkrise kommt in deutschen Haushalten an. Frankfurter Rundschau online (31 October). Retrieved from http:// www.fr-online.de/wirtschaft/finanzkrise-kommt-in-deutschen-haushalten-an/-/1472780/4692090/-/view/asFirstTeaser/-/index.html Schumann, H., \& Grefe, C. (2008). Der globale Countdown - Gerechtigkeit oder Selbstzerstörung - die Zukunft der Globalisierung. Cologne. Sinn, H.W. (2009). Kasino-Kapitalismus - Wie es zur Finanzkrise kam und was jetzt zu tun ist. Berlin.

Smith, J.S. (2014). A Concise History of the New Deal. Cambridge. https://doi.org/10.1017/CB09781139021258

Soboczynski, A. (2005). Der New Deal. Der Tagesspiegel.de (17 January). Retrieved from http://www.tagesspiegel.de/zeitung/der-newdeal/v_default,577794.html

Soros, G. (2009). Die Analyse der Finanzkrise ... und was sie bedeutet - weltweit. Munich.

Steinbrück, P. (German Federal Ministry of Finance). Press release and government statement of 25.09 .2008 on the state of the financial markets.

Strotz, P. (2007). Verkauf aus höchster Not. Zeit Online (26 August). Retrieved from http://www.zeit.de/online/2007/35/verkauf-sachsenlb-lbbw-perfekt?from=rss

Stroisch, J., Jeimke-Karge, H., Brück, M., \& Detering, M. (2009). Chronik: Finanzkrise: Vom Immobilienboom zum Börsen-Crash. Retrieved from http://www.wiwo.de/finanzen/finanzkrise-vom-immobilienboom-zum-boersen-crash-271063

Svennilson, I. (1954). Growth and Stagnation in the European Economy. Genf.

Temin, P., \& Voth, H.J. Wirtschaftskrise - So fern und doch so möglich.Zeit Online. Retrieved from http://www.zeit.de/2001/44/200144_g-depression.neu.xml

Tett,G.Genesisofthedebtdisaster.(2009).FinancialTimes(1May).Retrievedfromhttps://www.ft.com/content/51f425ac-351e-11de-940a-00144feabdc0

Ullmann, H. P. (2003). Kriegswirtschaft. Hirschfeld, Gerhard/Krumeich, Gerd/Renz, Irina (Eds.). Enzyklopädie Erster Weltkrieg. Paderborn (et. al.)

Wagemann, E. (Ed.). (1935). Konjunkturstatistisches Handbuch 1936. Berlin..

Weber, M. (2011). Wirtschaftsgeschichte - Abriß der universalen Sozial- und Wirtschaftsgeschichte. Aus den nachgelassenen Vorlesungen hrsg. von Siegmund Hellmann und Melchior Palyi (Eds.). Berlin. https://doi.org/10.3790/978-3-428-53511-8

Without author. (2008). Die Konjunktur kippt Retrieved from http://www.tagesschau.de/wirtschaft/chronologiefinanzmarktkrise108.html Without author. (2009). Der Staat steigt bei der Commerzbank ein. Retrieved from http://www.tagesschau.de/wirtschaft/chronologiefinanzmarktkrise112.html

Without author. (2009). Arcandor insolvent. Handelsblatt online (1 December). Retrieved from http://www.handelsblatt.com/archiv/juni2009/3316220.html

Woyke, W. (1985). Internationale Bank für Wiederaufbau und Entwicklung/Weltbank. Andersen, Uwe (Ed.). Handbuchwörterbuch Internationale Organisationen. Wiesbaden.

Woytinsky, W.(1932). Das Wirtschaftsprogramm der Reichsregierung. Die Arbeit - Zeitschrift für Gewerkschaftspolitik und Wirtschaftskunde. Heft 10 Zandi, M. (2009). Financial Shock: A 360 Degree Look at the Subprime Mortgage Implosion, and How to Avoid the Next Financial Crisis. New Jersey. Zeise, L. (2009). Das Ende der Party - Die Explosion im Finanzsektor und die Krise der Weltwirtschaft. Cologne.

Zschaber, M. C. (2010). Der Aufschwung kommt - Warum es mit der Wirtschaft jetzt aufwärts geht und wie Sie davon profitieren können. Frankfurt a. M.

\section{Finančne krize v primerjalni perspektivi - krizni menedžment in fenomen ponovitve/vrnitve}

\section{Izvleček}

Odkar obstajajo krize, njihov izbruh sproža pozornost v naši družbi in tesnobo glede naših tekočih interesov. Finančne krize, ki so incidenti pojava, šokirajo ekonomski svet in vladam postavijo znatne izzive. Krizi, ki izstopata iz tega konteksta, sta velika depresija 1929 in finančna kriza 2007/2008. Poleg komparativnega pristopa članek nameni pozornost tipičnemu mehanizmu ponovitve (npr. Reinhart in Rogoff, 2011: »ponavljajoči se vzorec bančnih kriz in kriz suverenega dolga«): pregrevanje, oblikovanje mehurčka, pok mehurčka, kar se je večinoma začelo v ZDA. Posebna področja te raziskave so krizni menedžment $v$ gornjih desetletjih, vloge vlad in bank, kot tudi ocena, katero naslednjo krizo lahko pričakujemo. Zaključimo lahko, da je trenutni monetarni sistem, ki ga vodijo kompleksni finančni instrumenti in je odvisen od nizkih obrestnih mer, nagnjen k nastanku še ene resne finančne krize.

Ključne besede: finančne krize, primerjava kriz, krizni menedžment, vladni ukrepi, prihodnja neizogibnost 